\title{
Epidemiological situation of bovine brucellosis after implementation of a vaccination program in Rio Grande do Sul State, Brazil
}

\author{
Situação epidemiológica da brucelose bovina após a implementação \\ do programa de vacinação no Estado do Rio Grande do Sul, Brasil
}

\author{
Nairléia dos Santos Silva ${ }^{1}$; Ana Cláudia Mello Groff²; Ana Carla Martins Vidor²; \\ José Henrique Hildebrand Grisi-Filho ${ }^{3}$; Marcos Bryan Heinemann ${ }^{3}$; \\ Ricardo Augusto Dias ${ }^{3}$; Evelise Oliveira Telles ${ }^{3}$; Vitor Salvador Picão Gonçalves ${ }^{4}$; \\ Marcos $\mathrm{Amaku}^{3}$; Fernando Ferreira ${ }^{3}$; José Soares Ferreira Neto $^{3 *}$
}

\begin{abstract}
This study aimed to evaluate the effectiveness of a bovine brucellosis vaccination program in Rio Grande do Sul, with prevalence as the indicator, and to identify risk factors for the disease. The state was divided into seven regions. For each region, a predetermined number of properties were randomly sampled, in which a pre-established number of randomly selected females aged over 24 months were tested. The serodiagnosis protocol consisted of a screening test using buffered acidified antigen, followed by a confirmatory test using 2-mercaptoethanol. An epidemiological questionnaire was utilized to identify possible risk factors associated with bovine brucellosis. In the state of Rio Grande do Sul, the prevalence of infected herds was found to be 3.54\% [2.49-4.88], and the prevalence of infected animals was $0.98 \%$ [0.57-1.57]. In assessments of specific regions, the infected herd prevalence ranged from $0.66 \%$ to $3.09 \%$, and among the animals, from $0.06 \%$ to $2.03 \%$. In herds comprising 15 or more cows, beef type and pasture sharing emerged as risk factors for bovine brucellosis in the state. The epidemiological status of bovine brucellosis in Rio Grande do Sul has remained unchanged since 2004, even though adequate vaccination coverage has been recorded since 2009. Thus, the state should continue its vaccination program, with emphasis on the quality of the process and on encouraging the use of nonantibody inducing vaccines. In addition, the state must make a greater effort to educate producers on the importance of testing for brucellosis in breeding animals before introducing them onto their properties, and on the importance of avoiding shared grazing among herds whose health conditions are unknown. Key words: Brucella abortus. Prevalence. Risk factors. Vaccination. Rio Grande do Sul. Brazil.
\end{abstract}

\section{Resumo}

O estudo objetivou avaliar a eficácia do programa de vacinação contra brucelose bovina no estado do Rio Grande do Sul tendo como indicador a prevalência e individualizar os fatores de risco para a doença. O Estado foi dividido em sete regiões. Para cada região foram amostradas aleatoriamente um número

\footnotetext{
${ }^{1}$ Discente, Faculdade de Medicina Veterinária e Zootecnia, Universidade de São Paulo, USP, São Paulo, SP. Brasil. E-mail: leiavet@gmail.com

${ }^{2}$ Médicas Veterinárias, Secretaria da Agricultura, Pecuária e Irrigação do Estado do Rio Grande do Sul, SEAPI-RS, Porto Alegre, RS. Brasil. E-mail: ana-groff@agricultura.rs.gov.br; ana-vidor@agricultura.rs.gov.br

3 Profs., Faculdade de Medicina Veterinária e Zootecnia, Universidade de São Paulo, USP, São Paulo, SP. Brasil. E-mail: grisi@, vps.fmvz.usp.br; fernando@vps.fmvz.usp.br; amaku@vps.fmvz.usp.br; dias@vps.fmvz.usp.br; evelise@vps.fmvz.usp.br; marcosbryan@usp.br; jsoares@vps.fmvz.usp.br

${ }^{4}$ Prof., Faculdade de Agronomia e Medicina Veterinária, Universidade de Brasília, UNB, Brasília, DF, Brasil. E-mail: vitorspg@ unb.br

*Author for correspondence
} 
preestabelecido de propriedades nas quais foi testado um número também preestabelecido de fêmeas com idade igual ou superior a 24 meses, aleatoriamente selecionadas. O protocolo do sorodiagnóstico foi composto de triagem com o teste do antígeno acidificado tamponado, seguido de teste confirmatório dos positivos com o teste 2-Mercaptoetanol. Nas propriedades foi aplicado um questionário epidemiológico sobre possíveis fatores de riscos associados à brucelose bovina. No estado do Rio Grande do Sul, a prevalência de focos foi de 3.54\% [2.49 - 4.88] e a de animais $0.98 \%$ [0.57 - 1.57]. Nas regiões, as prevalências de focos variaram de $0.66 \%$ a $9.03 \%$ e a de animais de $0.06 \%$ a $2.03 \%$. Rebanhos com 15 ou mais vacas, tipologia corte e compartilhamento de pastagens emergiram como fatores de risco para brucelose bovina no estado. A situação epidemiológica da brucelose bovina no Rio Grande do Sul manteve-se estável desde 2004, a despeito de boas coberturas vacinais terem sido registradas a partir de 2009. Assim, o estado deve continuar seu programa de vacinação, dando ênfase para a qualidade do processo e estimulando a utilização da vacina não indutora de anticorpos. Adicionalmente, o estado deve realizar um grande esforço de educação para que os produtores testem os animais de reprodução para brucelose antes de introduzi-los em suas propriedades e evitem o compartilhamento de pastagens entre rebanhos de condição sanitária desconhecida.

Palavras-chave: Brucella abortus. Prevalência. Fatores de risco. Vacinação. Rio Grande do Sul, Brasil.

\section{Introduction}

Rio Grande do Sul (RS) is the southernmost Federal Unit of Brazil, located in the extreme south of the country. It is the ninth largest Brazilian state by area, covering 281,731,445 $\mathrm{km}^{2}$ (IBGE, 2010). The occupation of this territory by Brazil occurred following several disputes with the neighboring countries of Uruguay, Argentina, and Paraguay. The gauchos, the colloquial term for the people of southern Brazil, spread across the fields along with their cattle, occupying the South of Brazil. As a result, cattle herding played a key role in the socioeconomic formation of the state. Currently, RS has a herd of 14 million cattle, making it the sixth largest herd in Brazil and the largest in the Southern Region (IBGE, 2013).

Agribusiness, specifically cattle, is a sector that is highlighted in the economy not only in RS, but also in the entire country. Every year, this solidifies Brazil's leading position in the international meat trade. Bovine brucellosis, a zoonotic disease causing economic losses, hinders the development of the beef production chain, and can result in barriers to international trade in animals and animal products (PAULIN; FERREIRA NETO, 2002, 2003).

For these reasons, the Ministry of Agriculture, Livestock and Supply (MAPA) created the National Program for Control and Eradication of Animal Brucellosis and Tuberculosis (PNCEBT) in 2001.
These are measures in line with the recommendations of the OIE (World Organisation for Animal Health), and are sufficiently flexible as to allow implementation of the program in heterogeneous regions of Brazil (LAGE et al., 2006; POESTER et al., 2009).

Since the inception of PNCEBT, standardized epidemiological studies have been conducted in 18 Federative Units. The studies have shown that the prevalence of infected herds ranges from $0.32 \%$ in Santa Catarina to $41.5 \%$ in Mato Grosso do Sul (ALVES et al., 2009; AZEVEDO et al., 2009; CHATE et al., 2009; DIAS et al., 2009a, 2009b; GONÇALVES et al., 2009a, 2009b; KLEINGUNNEWIEK et al., 2009; MARVULO et al., 2009; NEGREIROS et al., 2009; OGATA et al., 2009; ROCHA et al., 2009; SIKUSAWA et al., 2009; SILVA et al., 2009; VILLAR et al., 2009; BORBA et al., 2013; ALMEIDA et al., 2016; CLEMENTINO et al., 2016). The states of São Paulo, Minas Gerais, Espirito Santo, Rondônia, Mato Grosso, and Mato Grosso do Sul conducted a second brucellosis prevalence study in order to verify the effectiveness of their immunization programs. However, only in Mato Grosso, Mato Grosso do Sul, Minas Gerais, and Rondônia was a decrease in the prevalence of infected herds confirmed (BARDDAL et al., 2016; DIAS et al., 2016; ANZAI et al., 2016; INLAMEA et al., 2016; LEAL FILHO et al., 2016; OLIVEIRA et al., 2016). The state of Santa Catarina, which 
had the lowest prevalence of infected herds and animals, prohibited vaccinations and initiated the implementation of eradication strategies. Santa Catarina also conducted a second study that did not indicate a change in prevalence (BAUMGARTEN et al., 2016).

The study in Rio Grande do Sul was conducted in 2004, showing a 2.06\% [1.50-2.63] prevalence of infected herds and a $1.02 \%$ [0.60-1.43] prevalence of infected animals (MARVULO et al., 2009). At the time, it was recommended that the state implement a vaccination program for Regions 1, 2, 3 (south coast) and 7 (north coast), areas with increased prevalence of infection. Eradication strategies were suggested for Regions 4, 5 and 6, areas with a very low prevalence of infection. The state chose instead to implement a vaccination program in all of its territories, seeking to homogenize the state of health in the areas of high and low prevalence. In Rio Grande do Sul, immunization of heifers with B19 been required since 1965, but only after 2006 was the vaccination certificate mandatorily linked to the emissions of the Guide Animal Transit (GTA). The state was able to achieve acceptable rates of immunization coverage in 2009 (Figure 1).

Figure 1. Annual vaccination rate of heifers with B19 in the state of Rio Grande do Sul.

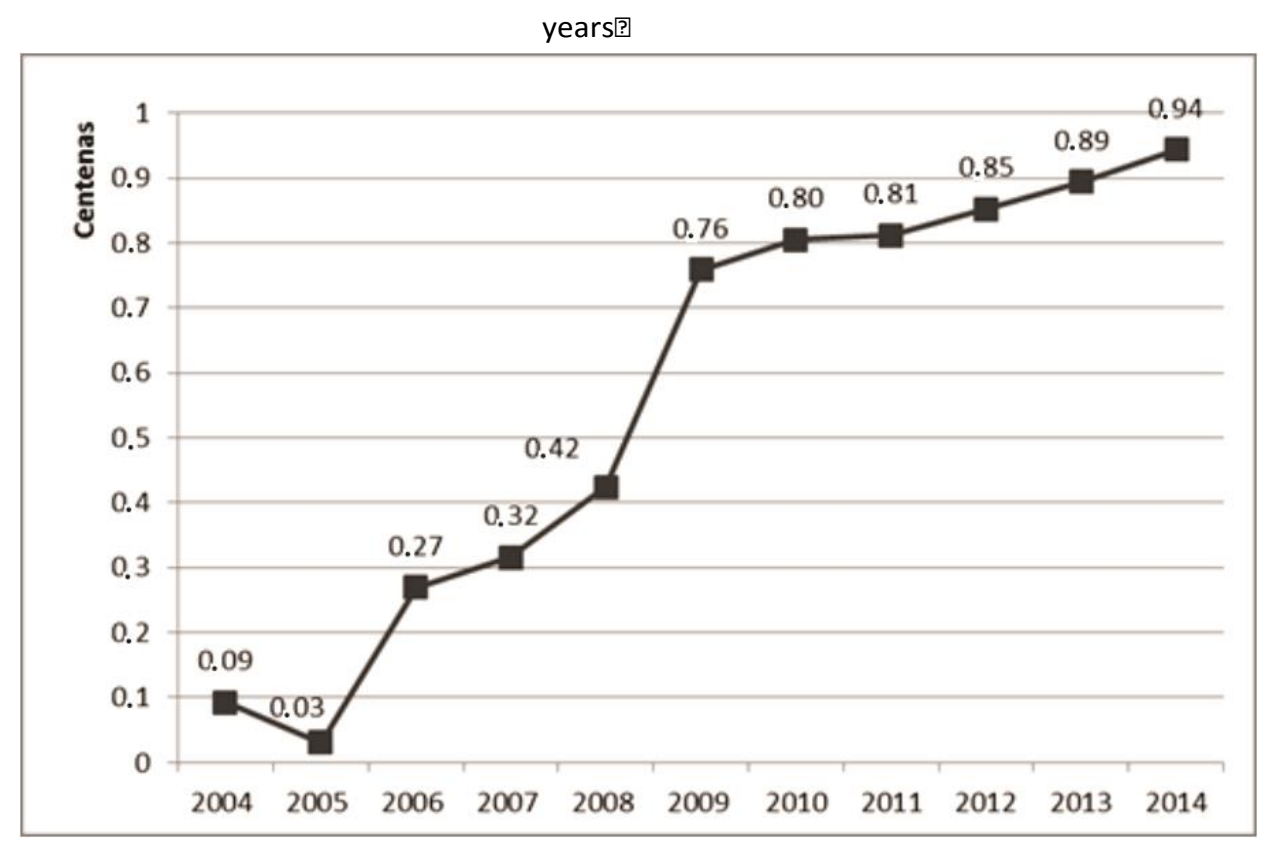

The objective of this study was to verify the effectiveness of the bovine brucellosis vaccination program implemented by the state, using the prevalence of infected herds and animals as an indicator. Additionally, the study sought to itemize the risk factors for introduction of the brucella infection to the aforementioned properties.

\section{Methods and Materials}

The epidemiological research study has been prepared by the Ministry of Agriculture, Livestock and Supply (MAPA) and the Collaborating Center for Animal Health of MAPA based out of the University of São Paulo. This was done in collaboration with the 
Animal Health Division (DSA) of the Department of Agriculture, Livestock and Irrigation of the state of Rio Grande do Sul (SEAPI-RS). Fieldwork was carried out by technicians from the DSA/SEAPI-RS.

Initially, the state was divided into regions based on the different production systems, management practices, type of operation, average size of the herd, animal marketing system, and the operational capacity of the animal health protection service. Within each of these regions, a predetermined number of properties with reproductive activity (primary sampling units) were randomly chosen. Within each selected property, a predetermined number of cows aged over 24 months were chosen at random (secondary sampling units).

On rural farms where there was more than one flock, the flock of greater economic importance was chosen. The animals must have been subjected to the same management, and therefore be under the same risk of exposure to infection. When a property that, for various reasons, could not be visited was chosen, another was drawn. The number of properties selected by region was determined by the formula for simple random samples (THRUSFIELD, 2007). The parameters adopted for the calculation were the following: a confidence level of 0.95 , an estimated prevalence of 0.20 , and a 0.05 error.

The sample design for the secondary units aimed to determine the minimum number of animals to be examined within each property, to allow for their classification as a herd that was infected, or not, with bovine brucellosis. Therefore, the concept of sensitivity and specificity aggregate was applied (DOHOO et al., 2003). For the purposes of calculation, values of 0.95 and 0.995 , respectively, were adopted for the sensitivity and specificity of the test protocol used (FLETCHER et al., 1998), and 0.20 for the estimated prevalence. Herdacc software version 3 was used for the sample size of choice to allow sensitivity and specificity values for the herd that were greater than or equal to $90 \%$. Thus, in properties with up to 99 females aged over 24 months, 10 animals were sampled, and in those with 100 or more females aged over 24 months, 15 animals were sampled. Females in the peripartum period, up to 15 days before or after delivery, were excluded from the selection.

Blood samples from all animals selected were collected between January and September 2013, by puncturing the jugular vein with a previously selected sterile disposable hypodermic needle connected to a vacuum tube. The sera obtained from the samples were frozen at $-20^{\circ} \mathrm{C}$ in polypropylene microcentrifuge tubes until the time of testing. The serodiagnosis protocol consisted of a screening test using buffered acidified antigen, followed by a confirmatory test using 2-mercaptoethanol. The tests were performed at the Desidério Finamor Veterinary Research Institute. A property was considered positive for brucellosis when at least one positive animal was identified.

The sample design allowed us to determine the prevalence of herds and adult females ( $\geq 24$ months of age) that were seropositive for brucellosis in the state and in the regions. Estimates of the prevalence and confidence intervals were calculated as recommended Dean et al. (1994by). Estimates of the prevalence of infected herds and animals in the state, and the prevalence of infected animals in the regions, were weighted according to a study by Dohoo et al. (2003).

The weight of each property in calculating the prevalence of infected herds in the state was given by:

$$
P_{1}=\frac{\text { properties in the region }}{\text { properties sampled in the region }}
$$

The weight of each animal in calculating the prevalence of animals in the state was given by:

$$
\begin{gathered}
P_{2}=\frac{\text { females } \geq 24 \text { months in the property }}{\text { females } \geq 24 \text { months sampled in the property }} x \\
\frac{\text { females } \geq 24 \text { months in the region }}{\text { females } \geq 24 \text { months sampled in the region }}
\end{gathered}
$$


In the expression above, the first term refers to the weight of each animal in the calculation of animal prevalence within the region.

Estimates of prevalence and confidence intervals of $95 \%$ were made using the R Core Team program.

At each sample property, in addition to the collection of blood samples for serological examination, answers to an epidemiological questionnaire designed to obtain information on the type of farming and management practices employed were also obtained.

The variables analyzed were as follows: type of operating system (meat, milk, mixed), type of breeding (confined, semi-confined, extensive), use of artificial insemination, predominant species, number of animals, presence of other domestic as well as wild species, occurrence of abortion in the last two years, destination of placenta and aborted fetuses, buying and selling of animals, vaccination against bovine brucellosis, pasture sharing with other properties, occurrence of flooding in the grasslands, existence of picket lambing and veterinary care.

The variables were arranged in an ascending scale of risk, and were recategorized when necessary. The lower risk category was considered as the basis of comparison for the other categories. Quantitative variables were categorized as percentiles. An exploratory analysis (univariate) was conducted for selection of those with $\mathrm{p}<0.20$ for the $\chi^{2}$ test (chi-square) or Fisher's exact test, and logistic regression was subsequently applied to these values as recommended by Hosmer and Lameshow (1989). The calculations were performed using the R Core Team program.

All information generated by field and laboratory work was included in a specific database, to be used for future epidemiological studies.

\section{Results}

The state was divided into seven regions (Figure 2). Samples were collected from 6,872 cows, on a total of 1,067 properties. Four properties were excluded due to the presence of animals with exclusively negative and/or inconclusive serological results. Table 1 provides a summary of census and sample data. Table 2 shows the prevalence of infected herds and animals in the region and the state. The prevalence of infected herds segregated by the type of farming in the region is shown in Table 3. Comparison of prevalence rates calculated by Marvulo et al. (2009) in 2004 with those found in the present study are shown in Figure 3.

Figure 2. Map of Rio Grande do Sul divided into regions.

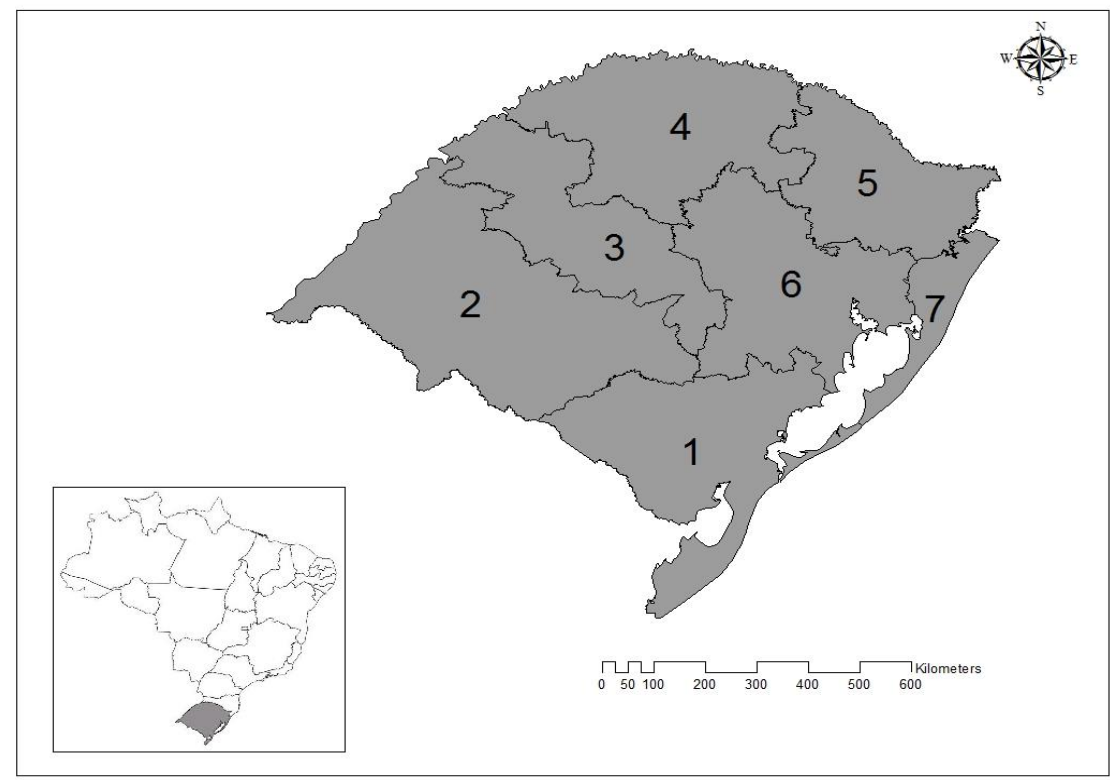


Figure 3. Comparison of prevalence of herds and animals infected with bovine brucellosis between the present study (2013) and one carried out in 2004 in the state of Rio Grande do Sul.

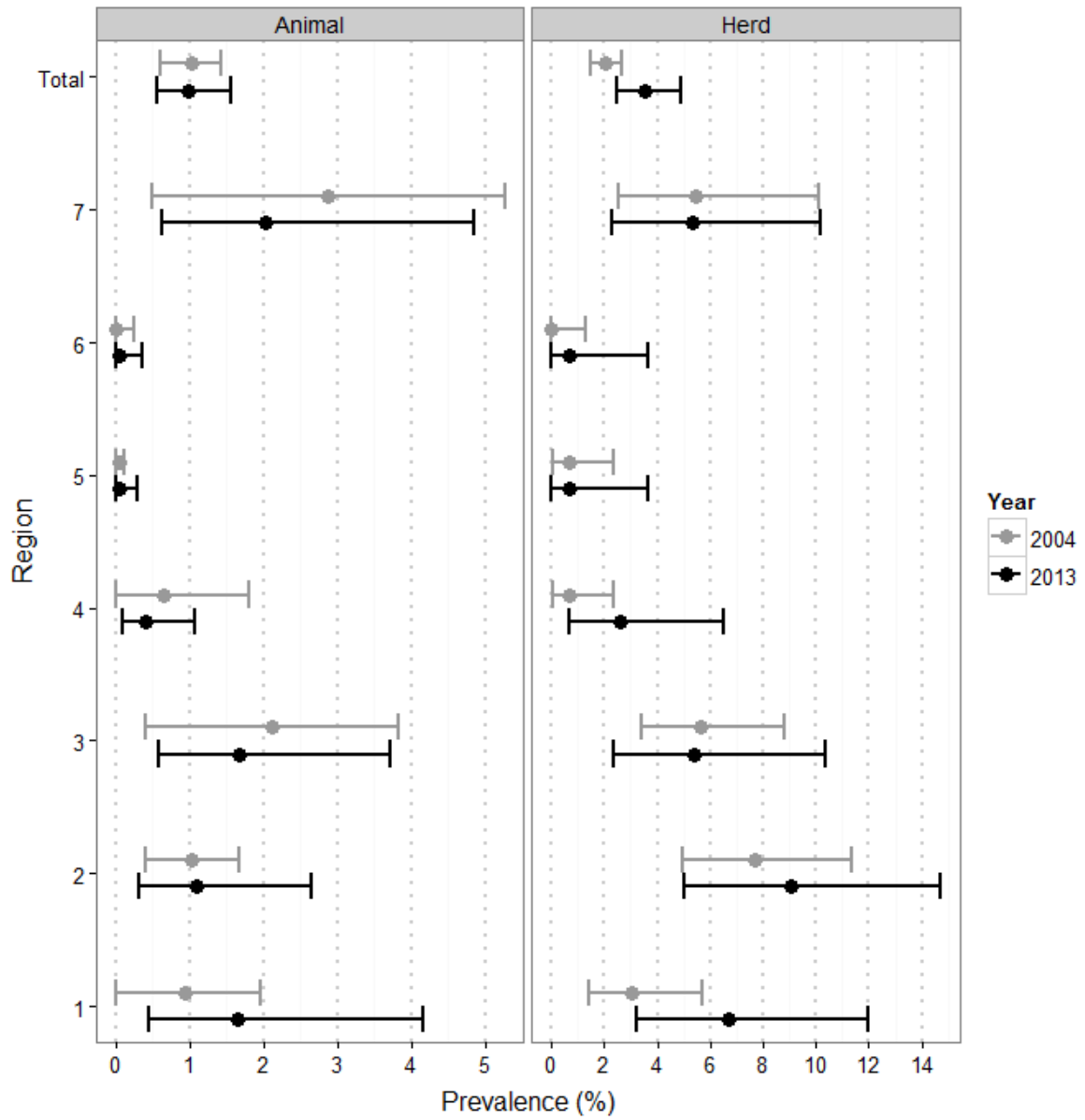

Table 1. Census and sample data from Rio Grande do Sul, in 2013.

\begin{tabular}{lcccc}
\hline Region & $\begin{array}{c}\text { Properties with re- } \\
\text { productive activity }\end{array}$ & Sampled properties & $\begin{array}{c}\text { Females } \geq 24 \text { months } \\
\text { of age in region }\end{array}$ & $\begin{array}{c}\text { Females } \geq 24 \text { months } \\
\text { of age sampled }\end{array}$ \\
\hline 1. South & 35,589 & 150 & 978,737 & 989 \\
2. West Frontier & 34,874 & 155 & $2,195,220$ & 1,403 \\
3. Central Missions & 47,483 & 149 & 937,859 & 1,075 \\
4. North & 93,888 & 155 & 899,861 & 997 \\
5. Sierra & 36,486 & 151 & 539,037 & 971 \\
6. Metropolitan & 73,259 & 152 & 746,561 & 748 \\
7. North Coast & 10,144 & 152 & 142,344 & 689 \\
\hline Total & 331,723 & 1,063 & $6,439,619$ & 6,872 \\
\hline
\end{tabular}


Table 2. Prevalence of herds and animals infected with bovine brucellosis in the state of Rio Grande do Sul, in 2013.

\begin{tabular}{lcccccc}
\hline \multirow{2}{*}{ Region } & \multicolumn{3}{c}{ Properties } & \multicolumn{3}{c}{ Females } \\
\cline { 2 - 7 } & $\begin{array}{c}\text { Positive / } \\
\text { sampled }\end{array}$ & Prevalence (\%) & CI 95\% (\%) & $\begin{array}{c}\text { Positive / } \\
\text { sampled }\end{array}$ & Prevalence (\%) & CI 95\% (\%) \\
\hline 1 & $10 / 150$ & 6.67 & $3.23-11.94$ & $17 / 989$ & 1.66 & $0.46-4.17$ \\
2 & $14 / 155$ & 9.03 & $5.02-14.71$ & $32 / 1,403$ & 1.09 & $0.33-2.65$ \\
3 & $8 / 149$ & 5.37 & $2.34-10.33$ & $12 / 1,075$ & 1.67 & $0.58-3.72$ \\
4 & $4 / 155$ & 2.58 & $0.70-6.49$ & $4 / 997$ & 0.40 & $0.10-1.08$ \\
5 & $1 / 151$ & 0.66 & $0.02-3.65$ & $1 / 971$ & 0.05 & $0.00-0.29$ \\
6 & $1 / 152$ & 0.66 & $0.02-3.63$ & $1 / 748$ & 0.06 & $0.00-0.36$ \\
7 & $8 / 152$ & 5.30 & $2.31-10.19$ & $14 / 689$ & 2.03 & $0.62-4.86$ \\
\hline Total & $46 / 1,063$ & 3.54 & $2.49-4.88$ & $81 / 6,872$ & 0.98 & $0.57-1.57$ \\
\hline
\end{tabular}

Table 3. Prevalence of herds infected with bovine brucellosis in regions of Rio Grande do Sul state, according to the type of production unit, 2013.

\begin{tabular}{lcccccc}
\hline \multirow{2}{*}{ Region } & \multicolumn{2}{c}{ Meat } & \multicolumn{2}{c}{ Milk } & \multicolumn{2}{c}{ Mixed } \\
\cline { 2 - 6 } & $\begin{array}{c}\text { Prevalence } \% \\
\left(\mathrm{p} / \mathrm{e}^{*}\right)\end{array}$ & CI 95\% $(\%)$ & $\begin{array}{c}\text { Prevalence } \% \\
\left(\mathrm{p} / \mathrm{e}^{*}\right)\end{array}$ & CI95\% $(\%)$ & $\begin{array}{c}\text { Prevalence \% } \\
\left(\mathrm{p} / \mathrm{e}^{*}\right)\end{array}$ & CI 95\% $(\%)$ \\
\hline 1 & $11.94(8 / 67)$ & $5.28-22.22$ & $1.79(1 / 56)$ & $0.04-9.59$ & $3.70(1 / 27)$ & $0.09-19.05$ \\
2 & $10.24(13 / 127)$ & $5.55-16.89$ & $5.26(1 / 19)$ & $0.13-26.13$ & $0.00(0 / 9)$ & $0.00-25.89^{1}$ \\
3 & $9.59(7 / 73)$ & $3.93-18.80$ & $0.00(0 / 40)$ & $0.00-7.05^{1}$ & $2.78(1 / 36)$ & $0.07-14.59$ \\
4 & $0.00(0 / 10)$ & $0.00-23.84^{1}$ & $3.33(3 / 90)$ & $0.69-9.46$ & $1.82(1 / 55)$ & $0.05-9.76$ \\
5 & $0.00(0 / 36)$ & $0.00-7.78^{1}$ & $0.00(0 / 72)$ & $0.00-4.02^{1}$ & $2.33(1 / 43)$ & $0.06-12.34$ \\
6 & $2.33(1 / 43)$ & $0.06-12.34$ & $0.00(0 / 57)$ & $0.00-5.03^{1}$ & $0.00(0 / 52)$ & $0.00-5.50^{1}$ \\
7 & $7.06(6 / 85)$ & $2.62-14.77$ & $0.00(0 / 17)$ & $0.00-15.33^{1}$ & $4.08(2 / 49)$ & $0.49-14.03$ \\
\hline
\end{tabular}

${ }^{*}$ positive/examined; ${ }^{1}$ Calculated using the Monte Carlo method and beta distribution.

The results of the univariate analysis are shown in Table 4, and the final logistic regression model for the risk factors associated with herds infected with bovine brucellosis in Rio Grande do Sul is shown in Table 5.

Table 4. Results of univariate analysis of potential risk factors for bovine brucellosis $(p<0.20)$ in the state of Rio Grande do Sul, in 2013.

\begin{tabular}{llccc}
\hline Variables & & Proportion of infected herds & $\%$ & $\mathrm{p}$ \\
\hline Vaccination with B19 & No & $1 / 346$ & 0.3 & $<0.001$ \\
& Yes & $45 / 696$ & 6.5 & $<0.001$ \\
Type of operation & Beef & $35 / 441$ & 7.9 & $<0.001$ \\
& Mixed & $5 / 351$ & 1.4 & $<0.001$ \\
& Milk & $6 / 271$ & 2.2 & $<0.001$ \\
Herd size & $<15$ adult females & $22 / 797$ & 2.8 & $<0.001$ \\
Slaughter with inspection & $\geq 15$ adult females * & $24 / 266$ & 9 & $<0.001$ \\
& No & $22 / 782$ & 2.8 & $<0.001$ \\
Slaughter on the farm & Yes & $24 / 281$ & 8.5 & $<0.001$ \\
& No & $32 / 476$ & 6.7 & 0.001 \\
& Yes & $14 / 587$ & 2.4 & 0.001
\end{tabular}


continuation

\begin{tabular}{|c|c|c|c|c|}
\hline \multirow[t]{3}{*}{ Number of milkings } & No milking & $31 / 429$ & 7.2 & 0.001 \\
\hline & 1 milking / day & 7/199 & 3.5 & 0.001 \\
\hline & 2 or 3 milkings / day & $6 / 356$ & 1.7 & 0.001 \\
\hline \multirow[t]{2}{*}{ Shared pasture } & No & $31 / 885$ & 3.5 & 0.010 \\
\hline & Yes & $14 / 165$ & 8.5 & 0.010 \\
\hline \multirow[t]{3}{*}{ Type of breeding } & Extensive & $39 / 679$ & 5.7 & 0.011 \\
\hline & Semi-confinement & $7 / 360$ & 1.9 & 0.011 \\
\hline & Confinement & $0 / 7$ & 0 & 0.011 \\
\hline \multirow[t]{2}{*}{ Shared water } & No & $35 / 929$ & 3.8 & 0.013 \\
\hline & Yes & $11 / 116$ & 9.5 & 0.013 \\
\hline \multirow{2}{*}{ Purchase of breeding animals } & No & $22 / 674$ & 3.3 & 0.027 \\
\hline & Yes & $24 / 377$ & 6.4 & 0.027 \\
\hline \multirow[t]{3}{*}{ Artificial insemination } & No & $36 / 633$ & 5.7 & 0.054 \\
\hline & Only insemination & $2 / 147$ & 1.4 & 0.054 \\
\hline & Insemination and bull & $8 / 217$ & 3.7 & 0.054 \\
\hline \multirow[t]{2}{*}{ Presence of delivery area } & No & $34 / 869$ & 3.9 & 0.114 \\
\hline & Yes & $12 / 183$ & 6.6 & 0.114 \\
\hline \multirow[t]{2}{*}{ Presence of goats / sheep } & No & $30 / 802$ & 3.7 & 0.114 \\
\hline & Yes & 16.261 & 6.1 & 0.114 \\
\hline \multirow[t]{2}{*}{ Acquisition of animals } & No & $21 / 584$ & 3.6 & 0.174 \\
\hline & Yes & $25 / 466$ & 5.4 & 0.174 \\
\hline
\end{tabular}

* third quarter.

Table 5. Final model of multiple logistic regression analysis of risk factors (odds ratio) for bovine brucellosis in herds with reproductive activity in the State of Rio Grande do Sul.

\begin{tabular}{lccc}
\hline Variable & Odds ratio & CI 95\% (\%) & $\mathrm{p}$ \\
\hline Size of herd $\geq 15$ female adults & 2.57 & $1.35-4.98$ & 0.004 \\
Beef-type use & 4.21 & $1.73-12.59$ & 0.004 \\
Sharing of pasture & 2.21 & $1.10-4.27$ & 0.020 \\
\hline
\end{tabular}

\section{Discussion}

The prevalence of brucellosis infection in the state of Rio Grande do Sul was 3.54\% [2.49 - 4.88] (Table 2). Considering the point estimates of the prevalence of infected herds (Table 2), there is a clear difference between two groups of regions. One group is composed of regions 1,2,3 and 7. This group has a higher prevalence of infection (ranging from $5.3 \%$ to $9.3 \%$ ), than the group composed of regions 4, 5 and 6 (prevalence rates ranging from $0.66 \%$ to $2.58 \%$ ). Regions 1, 2 and 3, whose properties have a greater number of animals as compared to the milk and mixed type properties, are highlighted due to the level of meat production (SANTOS et al., 2007). The median number of cows on meat, mixed, and milk type properties was 10,6 and 3, respectively. In fact, having more than 15 cows and having a beef-type herd emerged as risk factors for Brucella infection (Table 5). Region 7 is the north coastal region, and is characterized by small farms and very simple management practices. Regions 4 , 5 and 6 are located at the northern end of the state and have the highest number of farms and small herds which are dedicated mainly to the production of cow's milk (SANTOS et al., 2007). The data in Table 3 corroborate these findings. Marvulo et al. (2009) described the same distribution pattern of 
bovine brucellosis infected herds in Rio Grande do $\mathrm{Sul}$ in 2004. The prevalence of seropositive animals in the state was $0.98 \%$ [0.57 - 1.57] (Table 2), and the distribution of prevalence among the different regions illustrates the above findings.

As compared to the results obtained in 2004 (MARVULO et al., 2009), the prevalence of infection in Rio Grande do Sul calculated in this study did not show a statistically significant difference. Therefore, the vaccination program developed by the state did not result in lower prevalence rates. Similar results have been reported for São Paulo and Espírito Santo (DIAS et al., 2016; ANZAI et al., 2016). Thus, it is recommended that Rio Grande do Sul continue with their vaccination program, targeting vaccination coverage around 80\% (AMAKU et al., 2009), with an emphasis on the quality of the process, from marketing the vaccine to its application. Furthermore, the use of nonantibody inducing vaccines should be encouraged in adult animals, since this practice has been proven to result in a decrease in the prevalence of infection (SOUZA et al., 2016).

The final logistic regression model indicated that herds with 15 or more cows, beef type properties, and pasture sharing are factors associated with herd infection with bovine brucellosis in the state (Table 5).

The association between herd size and brucellosis has been reported by numerous international authors (KELLAR et al., 1976; NICOLETTI, 1980; SALMAN; MEYER, 1984). In Brazil, this association has also been found in the states of Rondonia, Rio de Janeiro, Sergipe, Tocantins, São Paulo, Mato Grosso do Sul and Mato Grosso (AGUIAR etal., 2007; KLEIN-GUNNEWIEK etal., 2009; SILVA et al., 2009; OGATA et al., 2009; DIAS et al., 2009b; CHATE et al., 2009; NEGREIROS et al., 2009). One characteristic of the larger herds which facilitates the transmission of brucellosis is the frequent replacement of animals. This makes it difficult to implement measures that control disease and the dynamics of brucellosis (CRAWFORD et al., 1990). Christie (1969) observed that increasing the herd size resulted in increased probability of occurrence, persistence of infection, and decreased likelihood of eradicating brucellosis. Therefore, the larger the herd, the greater the risk of introducing brucellosis, and the greater the likelihood of its intra-herd spread.

The fact that beef-type properties have shown a higher risk for brucellosis infection can likely be explained by the larger herd sizes. In the state, the median number of cows on beef-type properties was 10 , while on mixed it was 6 , and on milk, 3 .

Sharing of grazing pastures results in animals from different properties coexisting in the same environment. This increases the likelihood of contact between animals that are infected and those that are susceptible, since animals originating from different properties can have distinct health conditions. This is an indirect mode of contact between properties. Pasture rental, another indirect mode of contact between properties, has been reported as a risk factor for the spread of bovine brucellosis in the states of Parana and Rio de Janeiro. The practice of renting pastures may favor the contact of animals with previously contaminated environments. According to Wray (1975), the main risk factor for development of an infection with $B$. abortus is exposure to an environment contaminated with abortion products. Depending on the environmental conditions, abortion products may maintain viable brucella for up to 180 days (CRAWFORD et al., 1990).

\section{Conclusions}

The epidemiological status of bovine brucellosis in Rio Grande do Sul has remained unchanged since 2004 , in spite of the fact that appropriate vaccination coverage has been recorded since 2009. Thus, the state should continue its vaccination program, with emphasis on the quality of the process and on encouraging the use of non-antibody inducing 
vaccines. In addition, the state must make a greater effort to educate producers on the importance of testing for brucellosis in breeding animals before introducing them onto their properties, and on the importance of avoiding shared grazing among herds whose health conditions are unknown.

\section{Acknowledgements}

The authors acknowledge the logistical and financial support from the Animal Health Protection (DSA) teams of the Secretary of Agriculture, Livestock and Irrigation (SEAPI) of Rio Grande do Sul, MAPA, CNPq and FAPESP.

\section{References}

AGUIAR, D. M.; CAVALCANTE, G. T.; LABRUNA, M. B.; VASCONCELLOS, S. A.; RODRIGUES, A. A. R.; MORAIS, Z. M.; CAMARGO, L. M. A.; GENNARI, S. M. Risk factors and seroprevalence of Brucella spp. in cattle from western Amazon, Brazil. Arquivos do Instituto Biológico, São Paulo, v. 74, n. 4, p. 301-305, 2007.

ALMEIDA, E. C.; FREITAS, A. A.; PONTUAL, K. A. Q.; SOUZA, M. M. A.; AMAKU, M.; DIAS, R. A.; FERREIRA, F.; TELLES, E. O.; HEINEMANN, M. B.; GONÇALVES, V. S. P.; EVÊNCIO NETO, J.; MARVULO, M. F. V.; GRISI-FILHO, J. H. H.; FERREIRA NETO, J. S.; SILVA, J. C. R. Prevalence and associated risk factors for bovine brucellosis in the state of Pernambuco, Brazil. Semina: Ciências Agrárias, Londrina, v. 37, n. 5, p. 3413-3424, 2016. Suplemento 2.

ALVES, A. J. S.; GONÇALVES, V. P. S.; FIGUEIREDO, V. C. F.; LÔBO, J. R.; BAHIENSE, L.; AMAKU, M.; FERNANDO, F.; FERREIRA NETO, J. S.; DIAS, R. A. Situação epidemiológica da brucelose bovina no Estado da Bahia. Arquivo Brasileiro de Medicina Veterinária e Zootecnia, Belo Horizonte, v. 61, p. 6-13, 2009. Suplemento 1.

AMAKU, M.; DIAS, R.; FERREIRA NETO, J.; FERREIRA, F. Modelagem matemática do controle de brucelose bovina por vacinação. Arquivo Brasileiro de Medicina Veterinária e Zootecnia, Belo Horizonte, v. 61, p. 135-141, 2009. Suplemento 1.

ANZAI, E. K.; COSTA, D.; SAID, A. L. P. R.; GRISI-FILHO, J. H. H.; AMAKU, M.; DIAS, R. A.; FERREIRA, F.; GALVIS, J. O. A.; GONÇALVES, V. S. P.; HEINEMANN, M. B.; TELLES, E. O.; FERREIRA
NETO, J. S. An update on the epidemiological situation of bovine brucellosis in the state of Espírito Santo, Brazil. Semina: Ciências Agrárias, Londrina, v. 37, n. 5, p. 3437-3448, 2016. Suplemento 2.

AZEVEDO, S. S.; FERREIRA NETO, J. S.; DIAS, R. A.; FERREIRA, F.; AMAKU, M.; FIGUEIREDO, V. C. F.; LOBO, J. R.; GONÇALVES, V. S. P.; SOUZA, A. C.; VASCONCELLOS, S. A. Situação epidemiológica da brucelose bovina no Estado do Espírito Santo. Arquivo Brasileiro de Medicina Veterinária e Zootecnia, Belo Horizonte, v. 61, p. 19-26, 2009. Suplemento 1.

BARDDAL, J. E. I.; SANTOS, J. C. Q.; LOPES, I. F.; FERREIRA NETO, J. S.; FERREIRA, F.; AMAKU, M.; DIAS, R. A.; TELLES, E. O.; GRISI-FILHO, J. H. H.; HEINEMANN, M. B.; GONÇALVES, V. S. P.; AGUIAR, D. M. Effect of vaccination in lowering the prevalence of bovine brucellosis in the state of Mato Grosso, Brazil. Semina: Ciências Agrárias, Londrina, v. 37, n. 5, p. 3479-3492, 2016. Suplemento 2.

BAUMGARTEN, K. D.; VELOSO, F. P.; GRISI-FILHO, J. H. H.; FERREIRA, F.; AMAKU, M.; DIAS, R. A.; TELLES, E. O.; HEINEMANN, M. B.; GONÇALVES, V. S. P.; FERREIRA NETO, J. S. Prevalence and risk factors for bovine brucellosis in Santa Catarina state, Brazil. Semina: Ciências Agrárias, Londrina, v. 37, n. 5, p. 3425-3436, 2016. Suplemento 2.

BORBA, M. R.; STEVENSON, M. A.; GONÇALVES, V. S. P.; FERREIRA NETO, J. S.; FERREIRA, F.; AMAKU, M.; TELLES, E. O.; SANTANA, S. S.; FERREIRA, J. C. A.; LÔBO, J. R.; FIGUEIREDO, V. C. F.; DIAS, R. A. Prevalence and risk-mapping of bovine brucellosis in Maranhão State, Brazil. Preventive Veterinary Medicine, v. 110, n. 2, p. 169-176, 2013.

CHATE, S. C.; DIAS, R. A.; AMAKU, M.; FERREIRA, F.; MORAES, G. M.; COSTA NETO, A. A.; MONTEIRO, L. A. R. C.; LÔBO, J. R.; FIGUEIREDO, V. C. F.; GONÇALVES, V. S. P.; FERREIRA NETO, J. S. Situação epidemiológica da brucelose bovina no Estado do Mato Grosso do Sul. Arquivo Brasileiro de Medicina Veterinária e Zootecnia, Belo Horizonte, v. 61, p. 46-55, 2009. Suplemento 1.

CHRISTIE, T. E. Eradication of brucellosis in Northern Ireland: field problems and experiences. Veterinary Record, v. 85, p. 268-269, 1969.

CLEMENTINO, I. J.; DIAS, R. A.; AMAKU, M.; FERREIRA, F.; TELLES, E. O.; HEINEMANN, M. B.; GONÇALVES, V. S. P.; GRISI-FILHO, J. H. H.; FERREIRA NETO, J. S.; ALVES, C. J.; BEZERRA, C. S.; AZEVEDO, S. S. Epidemiological situation of bovine brucellosis in the state of Paraiba, Brazil. Semina: Ciências Agrárias, Londrina, v. 37, n. 5, p. 3403-3412, 2016. Suplemento 2. 
CRAWFORD, R. P.; HUBER, J. D.; ADAMS, B. S. Epidemiology and surveillance. In: NIELSEN, K.; DUNCAN, J. R. (Ed.). Animal brucellosis. Boca Raton: CRC Press, 1990. p. 131-151.

DEAN, A. G.; DEAN, J. A.; COULOMBIER, D.; BRENDEL, K. A.; SMITH, D. C.; BURTON, A. H.; DICKER, R. C.; SUlLIVAN, K.; FAGAN, R. F.; ARNER, T. G. Epi-Info 6: a word processing database, and statistics program for epidemiology on microcomputers. Atlanta: Center For Diseases Control And Prevention, 1994. $601 \mathrm{p}$.

DIAS, J. A.; MÜLLER, E. E.; DIAS, R. A.; FREITAS, J. C.; AMAKU, M.; FERREIRA, F.; SILVA, M. C. P.; LÔBO, J. R.; FIGUEIREDO, V. C. F.; GONÇALVES, V. S. P.; FERREIRA NETO, J. S. Situação epidemiológica da brucelose bovina no Estado do Paraná. Arquivo Brasileiro de Medicina Veterinária e Zootecnia, Belo Horizonte, v. 61, p. 66-76, 2009a. Suplemento 1.

DIAS, R. A.; BELCHIOR, A. P. C.; FERREIRA, R. S.; GONÇALVES, R. C.; BARÃO, R. S. C.; SOUSA, P. R.; SANTOS, A. M. A.; AMAKU, M.; FERREIRA, F.; TELLES, E. O.; GRISI-FILHO, J. H. H.; HEINEMANN, M. B.; GONÇALVES, V. S. P.; FERREIRA NETO, J. S. Controlling bovine brucellosis in the state of São Paulo, Brazil: results of ten years of vaccination program. Semina: Ciências Agrárias, Londrina, v. 37, n. 5, p. 3505-3518, 2016. Suplemento 2.

DIAS, R. A.; GONÇALVES, V. S. P.; FIGUEIREDO, V. C. F.; LÔBO, J. R.; LIMA, Z. M. B.; PAULIN, L. M. S.; GUNNEWIEK, M. F. K.; AMAKU, M.; FERREIRA NETO, J. S.; FERREIRA, F. Situação epidemiológica da brucelose bovina no Estado de São Paulo. Arquivo Brasileiro de Medicina Veterinária e Zootecnia, Belo Horizonte, v. 61, p. 118-125, 2009b. Suplemento 1.

DOHOO, I.; MARTIN, W.; STRIYHN, H. Veterinary epidemiologic research. Charlottetown: Atlantic Veterinary College, 2003. 706 p.

FLETCHER, R. H.; FLETCHER, S. W.; WAGNER, E. H. Clinical epidemiology: theessentials. $2^{\text {th }}$ ed. Baltimore: Williams \& Wilkins, 1998. 246 p.

GONÇALVES, V. S. P.; DELPHINO, M. K. V. C.; DIAS, R. A.; FERREIRA, F.; AMAKU, M.; FERREIRA NETO, J. S.; PORTO, T. B.; ALVES, C. M.; FIGUEIREDO, V. C. F.; LOBO, J. R. Situação epidemiológica da brucelose bovina no Estado de Minas Gerais. Arquivo Brasileiro de Medicina Veterinária e Zootecnia, Belo Horizonte, v. 61, p. 35-45, 2009a. Suplemento 1.

GONÇALVES, V. S. P.; RIBEIRO, L. A.; CALDAS, R. A.; FRANCISCO, P. F. C.; DIAS, R. A.; FERREIRA, F.; AMAKU, M.; FERREIRA NETO, J. S.; FIGUEIREDO,
V. C. F.; LOBO, J. R.; BORGES, J. R. J. Situação epidemiológica da brucelose bovina no Distrito Federal. Arquivo Brasileiro de Medicina Veterinária e Zootecnia, Belo Horizonte, v. 61, p. 14-18, 2009b. Suplemento 1.

HOSMER, D. W.; LAMESHOW, S. Applied logistic regression. New York: John Wiley and Sons, 1989. 307 p.

INSTITUTO BRASILEIRO DE GEOGRAFIA E ESTATÍSTICA - IBGE. Censo Demográfico. Brasília: IBGE, 2010. Disponível em: <http://www.ibge.gov.br/ estadosat/perfil.php?sigla=rs>. Acesso em: 05 jan. 2016.

. Produção da pecuária municipal. Rio de Janeiro: IBGE, 2013. v. 41, p. 1-108. Disponível em: <file:///C:/ Users/Zoonoses/Documents/Rio\%20Grande\%20do\%20 Sul\%20dados/ibge_2013.pdf > . Acesso em: 05 jan. 2016.

INLAMEA, O. F.; ROCHA, A. B.; FERREIRA, F.; GRISI-FILHO, J. H. H.; HEINEMANN, M. B.; DIAS, R. A.; TELLES, E. O.; GONÇALVES, V. S. P.; AMAKU, M.; FERREIRA NETO, J. S. Effect of vaccination in lowering bovine brucellosis in the state of Rondônia, Brazil. Semina: Ciências Agrárias, Londrina, v. 37, n. 5, p. 3493-3506, 2016. Suplemento 2.

KELLAR, J.; MARRA, R.; MARTIN, W. Brucellosis in Ontario: a case control study. Canadian Journal of Comparative Medicine, v. 40, n. 2, p.119-128, 1976.

KLEIN-GUNNEWIEK, M. F. C.; AMAKU, M.; DIAS, R. A.; FERREIRA, F.; GITTI, C. B.; PEREIRA, L. A.; FIGUEIREDO, V. C. F.; LOBO, J. R.; GONÇALVES, V. S. P.; FERREIRA NETO, J. S. Situação epidemiológica da brucelose bovina no Estado do Rio de Janeiro. Arquivo Brasileiro de Medicina Veterinária e Zootecnia, Belo Horizonte, v. 61, p. 77-84, 2009. Suplemento 1.

LAGE, A. P.; ROXO, E.; MÜLLER, E.; POESTER, F.; CAVALlÉRO, J. C. M.; FERREIRA NETO, J. S.; MOTA, P. M. P. C.; GONÇALVES, V. S. P. Programa nacional de controle e erradicação da brucelose e da tuberculose animal (PNCEBT). Brasília: Ministério da Agricultura, Pecuária e Abastecimento, 2006. 188 p.

LEAL FILHO, J. M.; BOTTENE, I. F. N.; MONTEIRO, L. A. R. C.; PELLEGRIN, A. O.; GONÇALVES, V. S. P.; FERREIRA, F.; DIAS, R. A.; AMAKU, M.; TELLES, E. O.; GRISI-FILHO, J. H. H.; HEINEMANN, M. B.; FERREIRA NETO, J. S. Control of bovine brucellosis from 1998 to 2009 in the state of Mato Grosso do Sul, Brazil. Semina: Ciências Agrárias, Londrina, v. 37, n. 5, p. 3467-3478, 2016. Suplemento 2.

MARVULO, M. F. V.; FERREIRA, F.; DIAS, R. A.; AMAKU, M.; GROFF, A. C. M.; GONÇALVES, V. S. P.; FIGUEIREDO, V. C. F.; LOBO, J. R.; FERREIRA NETO, J. S. Situação epidemiológica da brucelose bovina 
no Estado do Rio Grande do Sul. Arquivo Brasileiro de Medicina Veterinária e Zootecnia, Belo Horizonte, v. 61, p. 93-102, 2009. Suplemento 1.

NEGREIROS, R. L.; DIAS, R. A.; FERREIRA, F.; FERREIRA NETO, J. S.; GONÇALVES, V. S. P.; SILVA, M. C. P.; FIGUEIREDO, V. C. F.; LOBO, J. R.; FREITAS, J.; AMAKU, M. Situação epidemiológica da brucelose bovina no Estado do Mato Grosso. Arquivo Brasileiro de Medicina Veterinária e Zootecnia, Belo Horizonte, v. 61, p. 56-65, 2009. Suplemento 1.

NICOLETTI, P. The epidemiology of bovine brucellosis. Advances in Veterinary Science and Comparative Medicine, v. 24, p. 69-98, 1980.

OGATA, R. A.; GONÇALVES, V. S. P.; FIGUEIREDO, V. C. F.; LOBO, J. R.; RODRIGUES, A. L.; AMAKU, M.; FERREIRA, F.; FERREIRA NETO, J. S.; DIAS, R. A. Situação epidemiológica da brucelose bovina no Estado do Tocantins. Arquivo Brasileiro de Medicina Veterinária e Zootecnia, Belo Horizonte, v. 61, p. 126134, 2009. Suplemento 1.

OLIVEIRA, L. F.; DORNELES, E. M. S.; MOTA, A. L. A. A.; GONÇALVES, V. S. P.; FERREIRA NETO, J. S.; FERREIRA, F.; DIAS, R. A.; TELLES, E. O.; GRISIFILHO, J. H. H.; HEINEMANN, M. B.; AMAKU, M.; LAGE, A. P. Seroprevalence and risk factors for bovine brucellosis in the State of Minas Gerais, Brazil. Semina: Ciências Agrárias, Londrina, v. 37, n. 5, p. 3449-3446, 2016. Suplemento 2.

PAULIN, L. M.; FERREIRA NETO, J. S. A Experiência brasileira no combate à brucelose bovina. Arquivos do Instituto Biológico, São Paulo, v. 69, n. 2, p. 105-112, 2002.

O combate à brucelose bovina: situação brasileira. Jaboticabal: Fundação de Estudos e Pesquisas em Agronomia, Medicina Veterinária e Zootecnia, 2003. $154 \mathrm{p}$.

POESTER, F.; FIGUEIREDO, V. C. F.; LÔBO, J. R.; GONÇALVES, V. S. P.; LAGE, A. P.; ROXO, E.; MOTA, P. M. P. C.; MÜLLER, E. E.; FERREIRA NETO, J. S. Estudos de prevalência da brucelose bovina no âmbito do programa nacional de controle e erradicação de brucelose e tuberculose: introdução. Arquivo Brasileiro de Medicina Veterinária e Zootecnia, Belo Horizonte, v. 61, p. 1-5, 2009. Suplemento 1.

ROCHA, W. V.; GONÇALVES, V. S. P.; COELHO, C. G. N. F. L.; BRITO, W. M. E. D.; DIAS, R. A.; DELPHINO, M. K. V. C.; FERREIRA, F.; AMAKU, M.; FERREIRA
NETO, J. S.; FIGUEIREDO, V. C. F.; LÔBO, J. R.; BRITO, L. A. B. Situação epidemiológica da brucelose bovina no Estado de Goiás. Arquivo Brasileiro de Medicina Veterinária e Zootecnia, Belo Horizonte, v. 61, p. 27-34, 2009. Suplemento 1.

SALMAN, M. D.; MEYER, M. E. Epidemiology of bovine brucellosis in the Mexicali Valley, Mexico: literature review of disease-associated factors. Americam Journal Veterinary Research, v. 45, n. 8, p. 1557-1560, 1984.

SANTOS, D. V.; DUTRA, M. G. B.; GROFF, F. H. S. Vacinação do rebanho bovídeo gaúcho contra febre aftosa em janeiro de 2007. Hora Veterinária, v. 27, n. 159, p. 13-16, 2007.

SIKUSAWA, S.; AMAKU, M.; DIAS, R. A.; FERREIRA NETO, J. S.; MARTINS, C.; GONÇALVES, V. S. P.; FIGUEIREDO, V. C. F.; LÔBO, J. R.; FERREIRA, F. Situação epidemiológica da brucelose bovina no estado de Santa Catarina. Arquivo Brasileiro de Medicina Veterinária e Zootecnia, Belo Horizonte, v. 61, p. $103-$ 108, 2009. Suplemento 1.

SILVA, V.G. S. O.; DIAS, R.A.;FERREIRA, F.;AMAKU, M.; COSTA, E. L. S.; LOBO, J. R.; FIGUEIREDO, V. C. F.; GONÇALVES, V. S. P.; FERREIRA NETO, J. S. Situação epidemiológica da brucelose bovina no Estado de Sergipe. Arquivo Brasileiro de Medicina Veterinária e Zootecnia, Belo Horizonte, v. 61, p. 109-117, 2009. Suplemento 1.

SOUZA, V. A. F.; FERREIRA NETO, J. S.; AMAKU, M.; DIAS, R. A.; TELLES, E. O.; GRISI-FILHO, J. H. H.; HEINEMANN, M. B.; FERREIRA, F. Mathematical modeling of bovine brucellosis control using the RB51 vaccine. Semina: Ciências Agrárias, Londrina, v. 37, n. 5, p. 3767-3776, 2016. Suplemento 2.

THRUSFIELD, M. Veterinary epidemiology. $3^{\text {th }}$ ed. Cambridge: Blackwell Science, 2007. 610 p.

VILLAR, K. S.; AMAKU, M.; DIAS, R. A.; FERREIRA NETO, J. S.; BENITEZ, F.; GONÇALVES, V. S. P.; FIGUEIREDO, V. C. F.; LOBO, J. R.; FERREIRA, F. Situação epidemiológica da brucelose bovina no Estado de Rondônia. Arquivo Brasileiro de Medicina Veterinária e Zootecnia, Belo Horizonte, v. 61, p. 85-92, 2009. Suplemento 1.

WRAY, C. Survival and spread of pathogenic bacteria of veterinary importance within the environment. Veterinary Bulletin, v. 45, p. 543-550, 1975. 